\title{
O SUJEITO HÍBRIDO E A NÃO-PERTENÇA EM RUI KNOPFLI
}

\author{
Paula Terra Nassr ${ }^{1}$ \\ Daniel Conte ${ }^{2}$
}

\section{À GUISA DE INTRODUÇÃO}

As questões do sujeito híbrido knopfliano dentro de seu contexto de produção, serão abordadas neste estudo, detendo-se, especificamente, em poemas e recortes discursivos nos quais fica mais evidente o espaço da não-pertença. Não sendo um sujeito alinhado aos princípios do colonialismo e, também, não sendo aceito como sujeito engajado no contexto político pós-guerra de libertação, Knopfli acaba por seguir a diáspora e se exila em outros espaços em que possa se sentir acolhido, encontrando no seu discurso poético o refúgio para escapar ao não pertencimento.

$\mathrm{Na}$ ordem do sistema colonialista português, houve uma condição híbrida que apresentava um caráter poroso dentro das práticas identitárias entre colonizador e colonizado. A prática da ambivalência e da hibridez, segundo Boaventura Sousa Santos (2002), não foi uma reivindicação pós-colonial, mas a experiência do tipo de colonialismo que os portugueses seguiram durante anos. E desse processo surgiram os sujeitos que passaram a conviver com a coexistência das línguas, das culturas, dos modos de vida, contudo não foi uma convivência harmoniosa, sempre apresentou uma desigualdade e acentuou diferenças. Nesse entremeio, encontra-se o sujeito poético knopfliano que não se identificava com a ideologia imperialista à qual, consoante Said (2011), significa pensar, colonizar, controlar terras que não são nossas de modo que acabam por trazer miséria indescritível para os povos que habitam essas terras.

Essa era a base do colonialismo, a ideia não era somente acumular e adquirir, esse processo era sustentado e impelido por formações ideológicas que incluíam a noção de que certos territórios e povos precisavam ser dominados. O colonialismo como nos diz Cabaço (2009) consolidou, estruturalmente, uma oposição entre

\footnotetext{
${ }^{1}$ Universidade Federal do Rio Grande do Sul, Brasil.

${ }^{2}$ Feevale, Brasil.
}

Iluminuras, Porto Alegre, v. 20, n. 50, p. 121-145, julho, 2019. 
“civilizados" e "não civilizados", que sobreviveu com a mundialização da economia e do modelo político que dá continuidade ao processo hegemônico. A ideia era, também, desestruturar as sociedades tradicionais, fazer com que se acentuasse as rivalidades, além de se desprezar a cultura local.

A obra de Aimé Césaire, O Discurso sobre o colonialismo, nas relações e produções sobre a História afro-asiática, revela-se como um documento severo que narra as relações entre colonizador e colonizado. As independências das colônias africanas já haviam sido conquistadas, porém ao deparar-se com a avassaladora violência cultural, o autor escreve um texto em tom de denúncia sobre o que foi a prática colonialista. Nesse texto, mostra em um estilo ríspido, o motivo por que defende a máxima de que a "colonização desumaniza". A principal ideia defendida pelo escritor é de que a Europa era inflexível e apresentava uma incompetência administrativa, que trazia um conceito de colonização cruel e desenfreada legitimado pelo poder da Igreja e que, em nome de Deus, avassala o colonizado, impondo um silenciamento desestabilizador.

Césaire destaca que não há a possibilidade de se dar à Europa o grau de “colonizadora”, uma vez que não consegue solucionar seus problemas domésticos e se mostra uma civilização incapaz de resolver-se. O argumento é consolidado pelos exemplos históricos que traz e pela sua percepção sensível da violência praticada contra a África. Após explanações diversas, que conduzem à condenação da prática colonial, chega à conclusão de que ninguém coloniza inocentemente nem ninguém coloniza impunemente, que uma nação que coloniza, que uma nação que justifica a colonização - portanto, o uso a força - é já uma civilização doente, uma civilização moralmente ferida que, irresistivelmente, de consequência em consequência, de negação em negação, chama o seu Hitler, isto é, seu castigo (CÉSAIRE, 1978: 21).

O espaço de diálogo, dentro das relações estabelecidas pelos colonizadores, já nasce estéril, pois o valor atribuído ao Outro está dado já conceitualmente quando se pensa em colonizar, bem porque entre colonizador e colonizado "só há lugar para o trabalho forçado, a intimidação, a pressão, a polícia, o imposto, o roubo, a violação, as culturas obrigatórias, o desprezo, a arrogância, a suficiência, a grosseria, as elites 
descerebradas, as massas aviltadas" (CÉSAIRE, 1978: 25). Isso é resultado de algumas coisas que são geradas em um sistema que vai causar diásporas nas sociedades, menosprezar culturas, arruinar instituições seculares e provocar um silenciamento conceitual das produções artísticas. A Europa aniquila sociedades e corrompe culturas que vinham organizadas há centenas, milhares de anos. Atribui um valor positivo onde há sensibilidade etnográfica, impõe sua abominável criação: a ideia do "negro bárbaro". Com o dedo em riste, o autor profere seu discurso afirmando que dos

[...] valores inventados outrora pela burguesia e que ela lançou através do mundo, um é o do homem e do humanismo - e já vimos no que se tornou o outro é o da nação. É um facto: a nação é um fenômeno burguês. Mas justamente, se desvio os olhos do homem para contemplar as nações, constato que também aqui o perigo é grande; que a empresa colonial é, para o mundo moderno, o que o imperialismo foi para o mundo antigo: preparador do Desastre e precursor da Catástrofe. Pois então? [...] A verdade é que a perda da própria Europa está inscrita nessa política e que a Europa, se não se acautela, perecerá do vazio que criou a sua volta. (CÉSAIRE, 1978: 65)

É sobre essa existência baseada na desintegração das outras culturas que a burguesia implementa o sistema colonialista, mas por esse motivo está "condenada quer queira, quer não, a ser responsável por toda a barbárie da História, as torturas da Idade Média e a Inquisição, a razão de Estado e o belicismo, o racismo e o escravagismo" (CÉSAIRE, 1978: 57). Então, o que vai sobrar dessa destruição são os restos, e dessas sobras vai se construir na África a resistência. Sobre o medo se desenvolverá a luta, e sobre a expansão armada nascerá a república. Nesse contexto, há a emergência de uma funcionalidade colonialista antes não tida. Portugal foi incompetente em sua prática colonial, contudo conseguiu a desorientação necessária para o esmorecimento das referências nacionais, ou melhor, tribais dentro do território moçambicano.

$\mathrm{O}$ incentivo dado às guerras tribais, atualizando o secular conceito "dividir para dominar", trouxe uma aceleração no processo de deterioração referencial e estimulou a fragmentação tribal com o choque de culturas locais, o que retirava, em parte, do africano, o sentimento de colonizado, uma vez que o fazia se sentir superior ao seu igual e, por consequência, mais próximo de seu algoz: o colonizador. 
O sujeito poético de Knopfli é denunciador dessa situação colonial que considera injusta e fora do normal, não carrega consigo um complexo de culpa histórico, mas é um sujeito que expõe, poeticamente, com um senso trágico, a história colonial de Moçambique. Representa a condição do sujeito moçambicano, contudo recusa-se a aceitar africanidade como essência, entendendo-a como resultado de experiências vividas. É a partir da materialidade poética de Knopfli, amparando-se em Augé, Bachelard, Hall, Monteiro, Said, Subarits entre outros, que discutiremos a pemanência da imagem colonial no discurso do poeta moçambicano.

\section{A POESIA DE KNOPFLI E A PERMANÊNCIA DA IMAGEM COLONIAL}

Rui Knopfli afirma em entrevista (Chabal, 1994), que não há voz que exprima o descontentamento com a situação colonial como a sua, que nenhum intelectual português deu testemunho como o seu. Diz, ainda, que não poderia se sentir como um europeu unicamente porque tinha ascendência europeia; as vivências que lhe tocavam de perto o coração eram africanas. Quanto à questão do negro, afirmava que não poderia assumir as dores que não eram suas, mas que de longe reconhecia uma injustiça social, que era totalmente contra a existência de povos que governam outros povos.

Em seu primeiro livro publicado em 1959, O País dos Outros, os poemas denunciam severamente a condição colonial. O poema que inaugura a obra, já no primeiro verso, nos diz "Num céu de chumbo e baionetas caladas, [...] se anuncia a cólera do tempo." Tempo que mostrava o país que não era seu e que aos habitantes de Moçambique não mais pertencia, entretanto, era do sistema que vinha para emudecer a população, que trouxe um "muro de silêncio" e uma forma de viver "dissimulando na garganta o nó da angústia". Era difícil ser moçambicano, era difícil voltar-se contra o sistema colonialista, era uma fase de "desencontros, lampejos, quebrantos, instáveis desmoronamentos" em que ao sujeito poético lhe restava uma representação do real que o permitisse sobreviver ao caos e, assim, decreta: "simulo surdamente viver." 
No poema que segue, percebemos o sujeito poético estabelecendo uma posição de igualdade sócio-ideológica em relação às vozes silenciadas pelo processo colonial, essa é a forma que se apresenta em muitos poemas para mostrar-se opositor ao discurso opressivo daquele período histórico.

\section{Espreita o inescrutável}

Por veres-me doente e estendido, solitário na penumbra do quarto, o que tu pensas, Amigo!... Pensas-me músculos macerados, carne dolorida, silêncio de humanidades.

E como te enganas!...

Olha, vê... esta perna dói-me do joelho à cabeça do fémur, mas, escuta!, escuta o arranhar da vassoura no passeio, ouve a blandícia atónita das vozes que sobem da rua, atenta na canção que o negro chora nas cordas da viola e na lonjura.

Vês-me sombrio e quebrado debruçando-me, viagens pelo dicionário e sorris ao pontilhão de Apolo, à proveta cheia de vazio.

É verdade estão ocos, desencantados, despidos de sangue esses versos.

Mas, e como estão estes dias repetidos hora a hora, no fiar e desviar dos marasmos?

Vê, tudo como que pára e se suspende:

O cavador ergueu o busto, pousou a enxada e olha, no cais o negro, por momentos, arredou a carga e olha,

tu próprio pousas o livro e olhas.

Parámos,

o dia é igual,

o céu sem nuvens, igual.

Igual trilha a cigana de ontem.

Tudo é igual ao que já

antes era igual.

Todavia páramos e vamos erguendo os olhos.

Não sei o que se passa, todavia erguemos os olhos onde nenhuma contrariedade apaga esta fraca força de sempre esperar. E esperamos. (KNOPFLI, 2003:65-66) 
Nesses versos, também d'O País dos Outros, o sujeito poético ao seguir os percursos sombrios da memória, posiciona-se de forma igualitária aos sujeitos de vozes ciciadas e que estão destituídos de poder, assim o sujeito poético empresta a sua voz ao sujeito colonial, registrando em seus versos o silêncio que lhe foi imposto de forma social, política e histórica. Ao romper esse silêncio, o poeta associa-se com aquele sujeito na resistência, reconhecendo a humanidade da voz que nada pode gritar e que nada escuta "já senão o eco distorcido das palavras." Ao invocar "Amigo" nesse processo poético comunicacional entre um "eu" e um "tu”, traz um tom confessional e intimista em que esse "tu"/“Amigo" representa toda uma coletividade/humanidade: "Pensas-me músculos macerados,/carne dolorida, silêncio de humanidades." Porém, ao mesmo tempo, esse $t u$ representa o próprio sujeito poético como em um solilóquio, mostrando que a dor do silenciamento que ele sente pela coletividade se estende ao seu eu íntimo.

No poema Ofício Novo, que segue, podemos observar que o sujeito poético se encontra, novamente, em acordo com um tu poético oprimido pelo sistema colonialista:

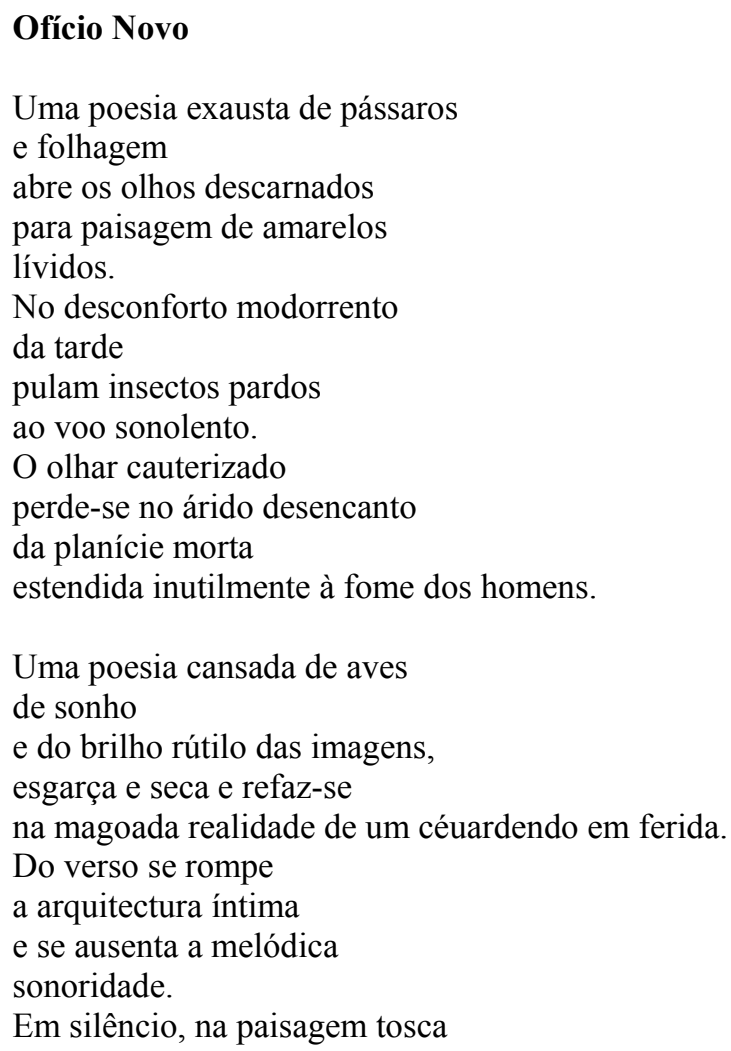


de gente magra e escura e triste, lentamente, aprendemos um ofício novo. (KNOPFLI, 2003:115)

O discurso que exala nesse poema é o da articulação entre melancolia e esperança. Aqui, o sujeito poético knopfliano insere-se, através de um "nós" que representa um coletivo africano, em que usa a metonímia expressa na "gente magra de pele escura". Esse "ofício novo", que é aprendido de forma coletiva e representa um resgate de uma humanidade perdida, transmite o sentimento e a denúncia anticolonial, bem como é a expressão de uma identificação entre o sujeito poético e o coletivo que evoca.

Na primeira estrofe, apresenta-nos uma crítica à poesia incapaz de revigorar-se a si mesma; uma crítica à estabilidade da imagem que vai, estável, perder sua força íntima; já na segunda, surge uma nova proposta de uma forma poética mais voltada à paisagem humana. Essa poesia que expressa a ideia "Do verso se rompe/ a arquitetura íntima" é a que ao trazer o coletivo evocado, assim como o próprio sujeito poético a si próprio, desemboca em uma aprendizagem de um "novo ofício", o da libertação individual e coletiva de todo um sistema opressor que se encerra "na magoada realidade de um céu ardendo em ferida".

Knopfli deu eco a essas vozes abafadas em um tom metafórico e essa era a sua forma de tomar partido, de demonstrar o seu descontentamento, não seguia a linha de seus contemporâneos, que adotavam uma forma mais panfletária de expor e criticar o sistema que silenciava e oprimia. E isso lhe trouxe dissabores no período em que o nacionalismo surgia com maior intensidade.

O autor recebeu críticas severas, conforme nos relata Monteiro (2003:31), "no período de recrudescimento nacionalista do Moçambique dos anos 60 e 70, quando o debate aberto de questões como raça e dominação eram condição sine quo non para o reconhecimento de "autenticidade", e, por isso, de "legitimidade", na representação literária africana."

O não-pertencimento se caracteriza, então, por esse viés também, assim como não se incluía em uma formação discursiva em que aceitava as agruras do 
colonialismo. Knopfli não foi aceito de forma plena nos círculos socioculturais por ser considerado menos engajado na luta de libertação. No mecanismo histórico vigente, só lhe restava ser um adepto às ideias do colonialismo português ou um ferrenho lutador pelos ideais do nacionalismo africano. É pela voz do poeta que ficamos sabendo que quando "a FRELIMO tomou conta do poder, o inimigo era o português, estou convencido disso. Claro que havia um certo racismo, aliás compreensível, mas, mesmo aí, os brancos eram identificados com os portugueses." (KNOPFLI apud Monteiro, 2003:27).

O deslocamento e a sensação de não-pertença do sujeito poético se apresenta em toda a obra, porém no período que antecede a saída do poeta da sua terra natal, e que culmina com a libertação de Moçambique em 1975, ele escreve a maior parte dos poemas do livro O Escriba Acocorado, publicado em 1978. Essa obra apresenta de forma amarga o momento intenso em que experienciava e onde o acento lírico põe na voz do sujeito poético uma mágoa trazida por perdas e pelo exílio do seu espaço. A seguir, dois poemas que compõem o referido livro e que evidenciam esses desconcertos do mundo como espaço externo, e do mundo como espaço interior do sujeito poético:

\section{Pátria}

Um caminho de areia solta conduzindo a parte nenhuma. As árvores chamavam-se casuarina, eucalipto, chanfuta. Plácidos os rios também tinham nomes porque era costume designá-los. Tal como as aves que sobrevoavam rente o matagal

e a floresta rumo ao azul ou ao verde mais denso e misterioso, habitado por deuses e duendes de uma mitologia que não vem nos tomos e tratados que a tais coisas é costume consagrar-se. Depois, com valados, elevações e planuras, e mais rios

entrecortando a savana, e árvores e caminhos, aldeias, vilas e cidades com homens dentro, a paisagem estendia-se a perder de vista até o capricho de uma linha imaginária. A isso chamávamos pátria. Por vezes, de algum recesso

obscuro, erguia-se um canto bárbaro e dolente, o cristal súbito de uma gargalhada, um soluço 
indizível, a lasciva surdina de corpos enlaçados.

Ou tambores de paz simulando guerra. Esta

não se terá feito anunciar por tal forma

remota e convencional. Mas o sangue adubou

a terra, estremeceu o coração das árvores

e, meus irmãos, meus inimigos morriam. Uma

só e várias línguas eram faladas e a isso,

por estranho que pareça, também chamávamos pátria.

De quatro paredes restaram as pedras. Com as folhas

de zinco e a madeira ferida dos travejamentos

perfaziam uma casa. Partes de um corpo

desmembrado, dispersas ao acaso, vento e silêncios

as atravessam e nelas não dura a memória

que em mim, residual, subsiste. Sobre escombros deveria,

talvez, chorar pátria e infância, os mortos que

lhe precederam a morte, o primeiro e o derradeiro

amor. Quatro paredes tombadas ao acaso e isso bastou

para que, no que era só mundo, todo o mundo entrasse

e o polígono demarcado, conservando embora a original configuração, fosse percorrido por um arrepio estrangeiro, uma premonição de gelos

e Inverno. Algo lhe alterara imperceptivelmente

o perfil, minado por secreta, pertinaz enfermidade.

Semelhante a qualquer outro, o lugar volvia meta

e ponto de partida, conceitos que, como a linha imaginária, circunscrevem, mas de todo eludem, o essencial.

Ladeado de sombras e árvores, o caminho de areia,

que se dizia conduzir a parte alguma, abria

para o mundo. A experiência reduz, porém, a segunda à primeira das asserções: pelo mundo

se alcança parte nenhuma; se restringe ficção

e paisagem ao exíguo mas essencial: legado

de palavras, pátria é só a língua em que me digo. (KNOPFLI, 2003:379380)

O primeiro verso, "um caminho de areia solta conduzindo a parte nenhuma", já nos desvela uma das concepções que o sujeito poético faz da pátria, espaço que deveria significar pertencimento a uma nação, uma comunidade, um país, um lugar de onde se origina alguém, mas como se apresentava historicamente esse espaço, só poderia levar a nenhum lugar reconfortante. Para sentir-se em um lugar, o sujeito precisa se identificar com ele, e o espaço precisa ser, conforme Augé (2014), identitário, relacional e histórico. Para o autor (2014, p.73) “um espaço que não pode se definir nem como identitário, nem como relacional, nem como histórico definirá 
um não lugar." Os não lugares quando "repertoriados, classificados e promovidos" passam a ser "lugares de memória." No caso, do sujeito poético o espaço de memória serve de amparo e na escrita encontra o seu espaço, o seu lugar.

Nas três primeiras estrofes do referido poema, observa-se que o sujeito poético nos apresenta uma pátria da paisagem, dos rios, da savana; esses são lugares de memória, da infância, de conforto. A pátria pode ser, aqui, sinônimo de casa na concepção bachelardiana: "é nosso canto no mundo." No fundo poético do espaço é onde há abrigo para o devaneio, onde o sonhador é protegido, é um espaço de conforto. A casa é um dos maiores poderes de integração de pensamentos, lembranças e sonhos, como bem nos evidencia Bachelard (1998: 201). Sem esse espaço, o homem seria um ser disperso, no caso do sujeito poético knopfliano é um ser que teve de se exilar da pátria, das paisagens reconfortantes, do espaço acolhedor da infância por conta da guerra, por se representar em um duplo espaço e pela divisão entre dois mundos culturais e geográficos: o ocidental e o africano.

Nas duas estrofes subsequentes, podemos observar uma outra pátria, "por estranho que pareça, também chamávamos de pátria”, mais agonizante: a da guerra, dos conflitos, das errâncias, onde "erguia-se um canto bárbaro e dolente" e o "sangue adubou a terra."

Depois de conduzir o leitor a uma espiral devaneante sobre a pátria da sua infância, rememorada via paisagens - espaço de conforto e da melancólica e realista lembrança do espaço da guerra "meus irmãos morriam”, vem as ruínas dessas duas pátrias simbolizadas em versos: "De quatro paredes restaram as pedras [...] partes de um corpo desmembrado" que só deixaram espaço para o vento e os silêncios e onde a memória não quis fazer morada.

A pátria que fora "meta e ponto de partida" torna-se um percurso onde não se alcança parte alguma e onde a ficção e a paisagem vão se restringir à herança das palavras e essa é a pátria que lhe resta: "a pátria é só a língua em que me digo.”

\section{O cão do Nilo}

Aqui deixo os mortos que me pertencem e os vivos 
com que me reparto. Cão do Nilo, sobreviverei bebendo na corrida, entre o ranger metálico das culatras e o bafo cálido da pólvora. Sigo ao sabor da corrente, um destroço à tona de água. Perto do fim, o cerco.

Adeus amigos, ternura diluída na neblina, começo a esquecer-vos. Perdoam-me os mortos, enigmáticos, sorrindo e escurece no corredor, envergonhada, a luz. De pura cobardia reincide o coração. Na margem do rio indistintos vultos acenam discretamente.

Transidas, não esvoaçam as aves de outrora, imóvel e erecto o canavial petrificado. Outras vozes sepultam já o eco da minha. Foragido, da memória irei por este mundo além. Amigos, fantasmas, nomes, lugares sabidos de cor, quero

chamar-vos esquecimento. Não estarei com os que verão o declive verdejante da montanha, não alcançarei a Terra Prometida. Errarei o resto de meus dias através de paragens inóspitas, levando comigo a vaga lembrança de um acesso país povoado de gentes,

coisas e lugares perdidos e sem rosto. $\mathrm{O}$ cabo enfreia a costa que do austro vinha correndo. Em temporais, vento e névoa, para sempre mergulhará o continente. Olho adiante.

Sobre meus ombros cerra-se, definitiva, a noite.

Além, álgida e glabra, abre-se a luz para onde me empurram tempo e fera ventura. No proscénio em que se desenrola a tragédia de Lear, a saga de Tamburlaine, ou a fúria sanguinária de Macbeth, serei comparsa anónimo revendo, nessas cenas,

lances bem outros e diferentes. Exausto de batalhas e combates que não travei, de conturbadas situações em que mais não fui que espectador passivo, dormirei por fim, transposto o limiar neutro e cinzento onde não há lápides, lembranças da pátria, ou de coisa nenhuma.

Meus irmãos, meus inimigos desaguados nos esgotos da Europa, irão urdindo sobre a indiferente, brônzea mirada dos algozes, espectros e sombras, por praças estrangeiras talhadas em granito, silêncio e desolação. Alcácer Quibir, melhor fora

ter adormecido no deserto, melhor fora repousar no leito das areias, convertido o sonho em ossada, brancura na distância. Pai, entre os torpes, fumegantes destroços do Império, teu filho esconde, o rosto e esgueira-se furtivo pelas malhas da diáspora. (KNOPFLI, 2003:392-393) 
Nos versos anteriores, o sujeito poético vai, como em tantos outros, mostrar-se uma testemunha dos acasos da história que lhe mudam o destino e o fazem sentir como um exilado em terras africanas, pelo fato de ter se inspirado nos ares da cultura europeia à época, que em Moçambique se vivia, o período do pós-guerras de libertação em 1975 e que se buscava "um só povo, uma só nação, uma só cultura", dessa forma, pensava o grande líder da revolução Samora Machel (1978). Segundo ele, era preciso criar um novo sujeito moçambicano atribuindo-lhe uma cultura mais ou menos compacta que se reinventasse por meio de um processo de reagregação de retalhos regionais e hibridismos, contudo o resultado final desse processo deveria ser um novo agregado singular, irredutível aos componentes da herança portuguesa.

A chamada moçambicanidade cultural deveria ser criada em contraposição a tudo que tenha sido influência da cultura portuguesa. Assim, o que restava aos poetas, escritores, enfim, a qualquer cidadão que não se incluísse nas premissas, era o movimento da partida. "Aqui deixo os mortos que me pertencem e os vivos com que me reparto [...] Sigo ao sabor da corrente, um destroço à tona de água [...] Adeus amigos [...] Foragido da memória irei por esse mundo além [...] não alcançarei a Terra Prometida.”

Podemos afirmar que o sujeito poético knopfliano passa pela desconfortante situação, de acordo com Bauman (2005), de estar totalmente deslocado em toda parte e de não estar totalmente em lugar algum pelo fato de ter uma identidade flutuante, ora sentindo-se africano pelas experiências culturais vividas no cotidiano da terra natal, ora sentindo-se português por carregar no sangue e nas leituras a genética ocidental. $\mathrm{O}$ fato de ter que se dispersar da terra de origem e se adaptar a ser um produto de culturas interconectadas, faz com que o sujeito híbrido pertença a várias casas, como nos explica Hall (2011) e, ao pertencer a essa cultura híbrida, o sujeito tem sido obrigado a renunciar ao sonho ou à ambição de redescobrir qualquer tipo de pureza cultural perdida, tornando-se um sujeito traduzido, que se transporta entre as fronteiras, que pertence a dois mundos ao mesmo tempo. Esse é o típico sujeito, que é resultado das novas diásporas criadas pelas migrações pós-coloniais. 
A situação que vive o sujeito híbrido desse contexto pós-colonial é, como vimos anteriormente, desconfortante, desequilibrante. No poema a seguir, veremos, uma vez mais, como isso se apresenta na poética de Knopfli:

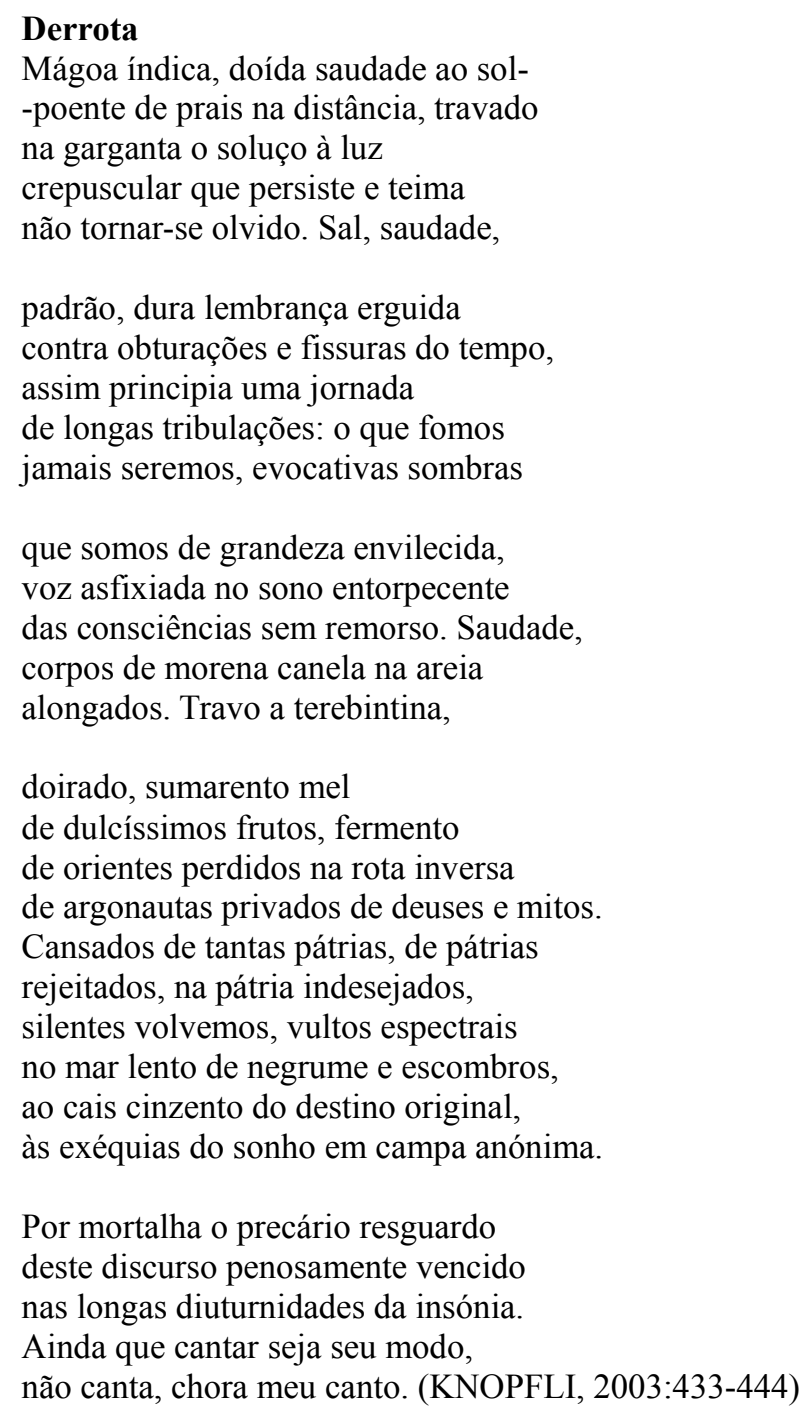

O poema representa já no seu título Derrota a sensação que o sujeito poético transmite em seus versos, a de um declínio, de uma perda de um tempo que a partir da vinda do colonizador só trouxe dor, silenciamento e saudade. "Mágoa índica, doída saudade $[\ldots]$ dura lembrança erguida contra obturações e fissuras do tempo, $[\ldots]$ voz asfixiada no sono entorpecente." Não há como nesse processo, voltar a ser o que se era antes, sob a forte influência e pressão do colonizador, o sujeito colonizado e o sujeito híbrido, que surge das mesclas culturais, ficam à sombra dos que os oprimem 
"o que fomos/ jamais seremos, evocativas sombras/ que somos de grandeza envilecida."

Os sujeitos têm de viver no conflito de pertencer a mais de uma pátria, a sua por naturalidade e, a outra, por obrigação (a do colonizador), ademais acaba por fugir e exilar-se em outra pátria que não a sua de origem. Então, são muitas das pátrias aos quais esses sujeitos são relegados: "Cansados de tantas pátrias, de pátrias/ rejeitados, na pátria indesejados," que lhes cabe ser vultos, escombros e se voltam seres silenciados: "silentes volvemos, vultos espectrais, no mar lento de negrume e escombros". A voz poética representa a voz do sujeito reprimido, asfixiado, que foi vencido, derrotado pela engrenagem de um tempo histórico nebuloso, desigual “ Por mortalha o precário resguardo/ deste discurso penosamente vencido/ [...] ainda que cantar seja meu modo,/ não canta, chora meu canto.”

Após o processo da colonização não há como haver um retorno puro às origens culturais, os efeitos culturais e históricos que a longo prazo formaram a nova mescla que caracterizou a experiência colonizadora tornaram-se irreversíveis. Consoante Hall (2003), as diferenças entre as culturas colonizadora e colonizada permanecem profundas, entretanto nunca operaram de forma absolutamente binária. A transição para o pós-colonial designa uma mudança em que a diferença, como dito anteriormente, não pode seguir uma ideia de binarismo, de um "antes" e um "agora". Esse período faz uma releitura dos binarismos como formas de transculturação, de tradução cultural, que vêm para perturbar os binarismos culturais do tipo aqui/lá.

Ao referir-se ao pós-colonial, Hall está referindo-se a uma releitura da colonização, que vai passar a ser parte de um processo global ${ }^{3}$ essencialmente transnacional e transcultural, que produz uma reescrita descentrada, diaspórica. Ademais, a noção do pós-colonial ${ }^{4}$ pode facilitar na descrição da mudança nas

3 A ideia de global, nesse sentido, não significa universal nem é algo específico a alguma nação ou sociedade. Trata-se como as relações transversais e laterais, conforme Gilroy (2001) denomina de diaspóricas, complementam e ao mesmo tempo deslocam as noções de periferia e centro, e de como o global e o local se reorganizam e se moldam um ao outro.

4 Importante destacar que o termo pós-colonial não marca o fechamento de um período histórico, porque o colonialismo e seus efeitos não terminam, definitivamente, com as independências. 
relações globais, que marca a transição irregular da era dos impérios para a conjuntura da pós-independência ou da pós-descolonização. Pode ser útil, também, de modo mais simbólico, na identificação das relações e disposições do poder que emergem nesse novo contexto.

Ao pensarmos como fica a questão da identidade no contexto pós-colonial, podemos constatar que as identidades se originam, de acordo com Mbembe (2014), na multiplicidade e na dispersão, que o voltar-se a si só é possível no entre-lugar, no interstício, entre a marca e a desmarca, em uma constituição paralela. A noção de sujeito e de identidade deixam de ser formas unitárias e essencialistas e tornam-se descentradas, assumindo novas posições discursivas. Nessa ordem, o conceito de hibridismo ou hibridação favorece a compreensão das identidades e dos processos de subjetivação a partir de um processo fluído de construção e desconstrução, negociações e lutas por reconhecimento. Desse modo, o sujeito híbrido da crítica póscolonial, é visto como descentrado e desterritorializado.

Esse "Outro" desterritorializado, o sujeito em devir, em mutação de si, em alteridade constituinte é o sujeito híbrido do qual fala Bhabha (2007). Esse sujeito descentrado é diverso, sempre "um outro". Possibilita-nos alcançar não apenas a diversidade enquanto dado, mas, também, enquanto (des)centramento, que inverte valores, em que a margem se coloca no centro, se torna a condição do ser, do devir: o vir a ser de Deleuze (1998), como um sujeito que se situa sempre entre dois mundos, assim observa o autor:

Devir é jamais imitar, nem fazer como, nem ajustar-se a um modelo, seja ele de justiça ou de verdade. Não há um termo de onde se parte, nem um ao qual se chega ou se deve chegar. Tampouco dois termos que se trocam. A questão "o que você está se tornando?" é particularmente estúpida. Pois à medida que alguém se torna, o que ele se torna muda tanto quanto ele próprio. Os devires não são fenômenos de imitação, nem de assimilação, mas de dupla captura, de evolução não paralela, núpcias entre dois reinos.(DELEUZE-PARNET, 1998:10)

O pós-colonial vai desfocar a referência no colonizador, apresenta, conforme Dirlik (1997), um problema de identidade tanto para o colonizado quanto para o colonizador. A constituição do Outro também é uma constituição do Eu. No caso do sujeito poético knopfliano, veremos aquele que fica à margem da relação binária por 
não ser nem o colonizado, nem o colonizador. É na ocorrência da cisão entre colonizador e colonizado que surge a vivência do entre-lugar, que é um viver nas fronteiras: "Uma experiência contingente, fronteiriça, se abre no intervalo entre colonizador e colonizado" (BHABHA, 2007 p. 284). Ocorre, nessa fissura que surge entre colonizador e colonizado, o movimento que se desloca do centro para as margens, locais habitados pela diferença. A partir desse movimento, o silenciamento pode deixar de ser comum como o foi em tempos obscuros do colonialismo.

O sujeito poético assume não estar em lado algum. "Exausto de batalhas e combates que não travei, de conturbadas situações em que mais não fui do que espectador passivo", ele não é partícipe da engrenagem histórica que ora deveria estar a favor dos desconcertos do colonialismo, ora deveria romper com tudo que estivesse vinculado ao legado do referido sistema em tempos de guerras de libertação do jugo colonial. Eis que representa o seu descontentamento com a situação vivida: "Pai, entre os torpes, fumegantes destroços do Império, teu filho esconde o rosto e esgueira-se furtivo pelas malhas da diáspora."

$\mathrm{Na}$ situação da diáspora, as identidades tornam-se múltiplas, o sujeito não é representação de uma única cultura, sabe-se bem, mas de todas as quais está em contato, mesmo que seja uma relação de contraposição. Não há como voltar para a cena primária, para a pátria como se fosse um renascimento, um recomeço, haverá uma sensação de deslocamento, de não mais pertencimento, o sujeito passa a viver como algo que está no meio, esperando através da memória, das vivências passadas poder retornar, poder pertencer. De acordo com Said (2000:52)

O problema é que, para a maioria dos exilados, a dificuldade reside, não só no fato de serem forçados a viver longe de casa, mas antes, e tendo em conta o mundo de hoje, em viver com inúmeras evocações de que estão no exílio, de que as suas casas não estão, na realidade, tão distantes, e de que o tráfego habitual do dia-a-dia da vida contemporânea os mantém em contato permanente, embora tantalizante e vazio, com o local antigo. Assim sendo, o exilado existe em um estado intermédio, nem completamente integrado no novo lugar, nem totalmente liberto do antigo, rodeado de semi-envolvimentos e semi-distanciamentos, nostálgico e sentimentalista, por um lado, imitador competente ou proscrito em segredo, por outro. 
O processo devastador do colonialismo não termina com a libertação conquistada em 1975, os sujeitos envolvidos ficaram maculados, o nacionalismo também deixou marcas, não há como sair ileso de um movimento tão significativo, se os sujeitos não se dedicam fielmente a uma causa comum de sua comunidade, país, nação. Assim, relata-nos Bauman (2003), quando se tratar de deveres comunitários, ao indivíduo não há escolha senão ser leal de forma incondicional à causa comum e não poderá ficar aquém da plena dedicação a essa causa. Caso agir de forma contrária, só lhe restará o exílio.

Ao falar da condição do sujeito no campo da política moderna e da noção de subjetivação, Rancière (1996:69) apresenta-nos um espaço em que há uma multiplicação das operações de subjetivação que inventam mundos de comunidade, esses mundos abrigam a divergência, são mundos comuns, porém não consensuais. Ainda referindo-se aos modos de subjetivação, trazemos, do autor, o excerto que segue (1996:69), o qual se mostra significativo para o entendimento da condição do sujeito poético Knopfliano:

Nem é o nós nem a identidade que lhe é atribuída, nem a aposição dos dois definem um sujeito. Só há sujeitos, ou, melhor, modos de subjetivação políticos, no conjunto de relações que o nós e seu nome mantêm com o conjunto das "pessoas", o jogo completo das identidades e das alteridades implicadas na demonstração, e dos mundos, comuns ou separados, em que se definem.

No excerto, percebemos o que Rancière denomina como um sistema de evidências revelador, simultaneamente, da existência de mundos comuns que abrigam recortes definidores de espaços e partes respectivas, isso significa que esse mundo comum partilhado apresenta tempos e tipos de atividades que caracterizarão, de fato, a funcionalidade existencial de uns e de outros os quais fazem parte dessa mesma rede de significação. Se pensarmos na individualidade de cada sujeito, temos de atentar às idiossincrasias que fazem com que ele tome parte no jogo das identidades e alteridades em função daquilo que faz, do tempo e do espaço que ocupa nesse mundo comum, o que define suas competências ou incompetências para transitar no espaço partilhado. 
Ao pensar no sujeito knopfliano, percebemos que ele não consegue fazer o trânsito no discurso colonialista nem estabelecer relações necessárias com o discurso nacionalista, que entra em vigor para rebater as ideologias do colonialismo. O sujeito poético knopfliano representa essa situação de exilado no seu próprio país, vê-se sitiado "na sombra vigiada" em ambos momentos históricos - colonialismo e nacionalismo pós-guerras de libertação. Não consegue se sentir pertencente: "ser estranho na própria terra"; e não pode fixar raiz: "sou desenraizado", expressando uma imensa vontade de poder voltar no tempo e ocupar o espaço que lhe foi negado, seus versos são como um fado dolente, um fado que sussurra os seus "silêncios desabitados" que guardam nos recantos da memória a "imagem doente do espaço outrora habitado."

O ensaísta espanhol Eduardo Subirats (2010), ao falar sobre um manifesto do escritor Klaus Mann, escrito em 1949, sobre a condição da Europa naquele período, observa que o ficcionista a apresenta, metaforicamente, como em crise permanente, em ruínas e escombros e tais metáforas são usadas, segundo ele, durante uma longa tradição europeia intelectual. Não bastasse, usa um termo heimsuchung, que designa a condição de perseguido, capturado ou fechado em sua morada, o que representa a condição do intelectual à época.

Assim, também, apresenta-se o sujeito de ascendência europeia em Moçambique no auge da libertação, por isso o discurso poético desvela essa situação em versos: "aqui ninguém sabe quem sou, aqui a minha importância é zero. Em Paris também." Os versos vêm arrastados pelo silenciamento desse sujeito sem importância e impregnados de denúncia da situação histórica, que excluiu intelectuais menos engajados nas causas políticas "somos de grandeza envilecida, voz asfixiada no sono entorpecente [...] Cansados de tantas pátrias, de pátrias rejeitados, na pátria indesejados."

A situação do exílio, do não-pertencimento, gera uma condição de não sentimento de ser, reflete em um desfalecimento da condição do sentir-se sendo parte de uma pátria. Subirats (2010) ao falar sobre intelectuais e o exílio, apresenta-nos os estigmas que vem a reboque com essa situação: o sentir-se desterrado, vivendo em 
ostracismo são situações que designam um estado de exclusão e isolamento do intelectual, o que demostra um deslocamento do espaço cultural e político da consciência reflexiva, mas, também, revelam uma ruptura e uma ferida profundas dessa consciência em relação ao seu tempo histórico e seu espaço social.

A condição de exilado define a impotência social e sua precariedade existencial. Nos fragmentos que seguem vemos desvelada essa conflituosa e triste situação: “Assim arrasto a minha inutilidade/e lembranças como feridas./ São o que de melhor tenho/ com o sonho esboroado daquilo que não fui [...]"(KNOPFLI, 2003:64). E, ainda: "E aqui a sombra de meus dias apodreço/na consumpção de ocultas/ corruptas brasas./ No que queria e afinal não sou, feneço.” (KNOPFLI, 2003:62).

O sujeito poético apresenta-se como um intelectual dissonante da sua pátria e da sua sociedade estando em conflito e desacomodação, sentiu-se exilado mesmo antes de sair, por isso de acordo com Said (2000:55)

\begin{abstract}
A matriz do percurso do intelectual não-acomodado encontra seu melhor exemplo na condição de exilado, na inadaptação latente, que o faz sentir-se fora do mundo familiar e da amena cavaqueira habitada pelos nativos, por assim dizer, com tendência a evitar, e até mesmo detestar, as armadilhas da acomodação e do bem-estar nacional. Para o intelectual, o exílio nesta acepção metafísica é o desassossego, o movimento, o estar sempre desinstalado e desinstalando os outros.
\end{abstract}

Essa situação que nos apresenta Said sobre o intelectual exilado é uma nova forma de viver e de sentir-se, torna-se um outro estilo de pensamento e uma nova habitação, um novo estilo de sobrevivência, é uma espécie de "amargura rezingona" como evidencia o autor.

No poema abaixo observamos, novamente, a situação de não pertença, de uma vivência repleta de sofrimento e de silêncios:

\title{
O Livro Fechado
}

Quebrada a vara, fechei o livro e não será por incúria ou descuido que algumas páginas se reabram e os mesmos fantasmas me visitem. Fechei o livro, Senhor, fechei-o,

mas os mortos e sua memória os vivos e sua presença podem mais 
que o álcool de todos os esquecimentos.

Abjurado, recusei-o e cumpro,

na gangrena do corpo que me coube,

em lugar que não lhe compete,

o dia-a-dia de um destino tolerado.

Na raça de estranhos em que mudei,

é entre estranhos da mesma raça

que, dissimulo e obediente, o sofro.

Aventureiro ,ou não, servidor apenas

de qualquer missão remota ao sol-poente,

em amanuense me tornei do horizonte

severo e restrito que me não pertence,

lavrador vergado sobre solo alheio

onde não cai, nem vinga, desmobilizada,

a sombra elíptica do guerreiro

Fechei o livro, calei todas as vozes,

contas de longe cobradas em nada.

Fale, somente os silêncios que lhes sucede. (KNOPFLI, 2003:478)

Vemos, no poema acima, que o sujeito poético manifesta um desejo de encerrar uma etapa, a imagem metafórica do fechar o livro, leva-nos à ideia de encerrar um ciclo, terminar de vez com um momento que só apresenta circunstâncias severas e tristes. Porém, fechar o livro não impede que esse passado volte à tona de forma mnemônica "e não será por descuido/ que algumas páginas se reabram/ e os mesmos fantasmas me visitem."

A situação no poema, refere-se a um momento histórico - o período colonial que marcou a vida dos envolvidos no processo, incluindo o sujeito híbrido formado a partir dos contatos culturais e ideológicos. Esse sujeito tornou-se um estranho, visto que não era o colonizador, nem o colonizado, não houve grupo a que se pudesse ajustar "em lugar que não lhe compete, o dia-a-dia de um destino tolerado./ Na raça de estranhos em que mudei, é entre estranhos da mesma raça que, dissimulado e obediente, o sofro." Sua pátria torna-se "horizonte severo e restrito que me não pertence" e "solo alheio", lhe restou ser sombra "sombra elíptica" e lhe restou a fuga e a melancolia mescladas a um silenciamento "Fechei o livro, calei todas as vozes [...] fale, somente, o silêncio que lhes sucede."

O sujeito poético, ao longo do seu percurso, vai revelando seus silêncios, suas dores, sua condição híbrida e, ao mesmo tempo, de não-pertença, porém é através dos 
seus versos que se volta a si mesmo, seu olhar passa a observar a sua voz interior, é dessa forma que busca a sua essência e sua "anódina paisagem" e que preenche "este meu silêncio antigo, com que incendeio de luzes esta escuridão que habito.”

\section{À GUISA DE CONSIDERAÇÕES FINAIS}

Os problemas do colonialismo não foram resolvidos ou, ainda, tornaram livres de conflitos os movimentos que se estendem do início da colonização à época do pósindependência. O período pós-colonial marca a passagem de uma configuração histórica de poder para outra. Hall relata que os problemas de dependência, subdesenvolvimento e marginalização, que eram típicos do alto período colonial, persistiram no depois das independências. Porém, com uma outra configuração. Antes as relações de poder eram articuladas de forma desiguais entre colonizadores e colonizados. Depois passaram a ser deslocadas para lutas entre forças sociais nativas, com contradições internas e fontes de desestabilização no interior da sociedade descolonizada. Nesse novo contexto o protetorado do poder imperial foi substituído por um sistema assimétrico com caráter pós-nacional e pós-imperial. Ademais, as questões de subjetividade são problematizadoras no sentido de que tanto ao colonizador quanto ao colonizado há uma crise de identidade.

Ao pensarmos questões a respeito do nacionalismo moçambicano no período pós-independência, percebemos que não há como conceber uma nova cultura sem a existência de uma cultura anterior à qual se opor. O processo é sempre relacional, a fabricação de uma nova identidade deve ser confrontada com uma velha identidade. No entanto, se no âmbito da teoria, para a formação da nova identidade moçambicana se deve romper com os valores da cultura colonial e da cultura tradicional, na prática esse processo atua sobre os sujeitos de maneira complexa. A nova configuração identitária é um produto cuja pureza nunca se irá alcançar, ao mesmo tempo que se apresenta altamente delicado o movimento de entender a tradição no espaço contemporâneo. 
As culturas pós-coloniais apresentam uma característica híbrida e transcultural, na medida em que há um entrelaçamento entre mundos diversos, o do colonizador e colonizado. No entremeio dessas culturas, porém, há o entre-lugar, espaço produzido na articulação de diferenças culturais, como enfatiza Bhabha, ao falar sobre novos espaços de subjetividade. Esse entre-lugar se caracteriza por elaborar estratégias de subjetivação que leva à produção de novos signos de identidades. É nesse entre-lugar que se encontra toda a confluência das diferenças culturais estabelecedora da organização dos novos signos que sedimentarão uma identidade outra, já reencenada e que faz do presente um tempo a ser construído.

O sujeito poético da obra de Rui Knopfli encontra-se, sem dúvida, nesse entrelugar das culturas híbridas marcadas pelo processo histórico que antes excluiu o sujeito colonizado e, após a independência, passou a excluir o sujeito que não se vinculava arduamente às lutas de libertação do jugo colonial português. A trajetória de produção poética desse sujeito é desdobrada em quatro décadas, engendrada em meio a utopias, rupturas e desconcertos, embora denuncie a questão colonial, não há um empenho em pôr sua palavra em prol meramente da causa revolucionária vigente. Isso lhe confere a acusação de ser desenraizado e apátrida. Atravessa seu tempo com a incômoda designação de um poeta sem lugar. Exila-se já na sua terra e fora dela. Torna-se um sujeito diaspórico, também, porque lhe negam, a princípio, a devida inserção nos círculos da poesia moderna moçambicana.

O que se desvenda nessa obra poética é algo além do que a visibilidade de um continente em necessária marcha à libertação, vai além dos discursos que reduziam a descolonização ao embate binário entre colonizador e colonizado, o que podemos ver nos versos, por vezes agônicos, é um sujeito híbrido que solicita o seu direito de ser africano "Europeu, me dizem./[...] mas africano eu sou." Ao passo que vai descortinando as agruras da colonização, o sujeito poético nos apresenta uma pátria multicultural, com rastros de interações multitemporais, únicas e contraditórias. Está em consonância com as tradições locais, pois transforma em espaço de escrita a Ilha de Moçambique "Ilha, velha ilha, metal remanchado, / minha paixão adolescente." 
Enquanto desmascara o silenciamento, a austeridade do período colonial "mudez feita de medo e simpatia", apresenta-nos um discurso áspero e sofrido de um sujeito que se constitui no bojo das experiências desiguais que são atravessadas e condicionadas por esse momento histórico. Knopfli Expõe as dores de um ser amputado de si e de seu meio. Fazer a leitura de uma obra poética knopfliana nos faz adentrar num sujeito e espaço rompidos, desgastados pelo decorrer da história. Período histórico esse em que se embatem o individual e coletivo, o negro e o branco, o eu e o tu, o passado e o futuro. No discurso poético notamos um sujeito consciente da ruptura com seu lugar, há a percepção de que o seu espaço e pátria "é só a língua em que me digo."

O labor poético é o espaço de construção do sujeito, onde junta os pedaços fraturados, onde busca fugir do silenciamento, das incertezas, dos obstáculos e obscuridades que lhe vieram à reboque por não se aceitar nem dentro do mundo colonialista português, nem do nacionalista africano. A escrita de poemas é o meio pelo qual o poeta se reconstrói ao mesmo tempo que ergue seu discurso contando a história da sua Moçambique, da sua África tão devastada pelos colonizadores. Nesse meio, o da poesia, tudo passa a ter sentido, das dores aos desejos de retorno, dos silêncios aos versos mais contundentes, críticos e cheios de ironia, cada fragmento de discurso poético é repleto de sentido, é repleto da ideologia desse sujeito marcado pelo tempo e pelo afastamento do seu lugar de conforto.

A respeito do sujeito híbrido e o não-pertencimento, o que percebemos é que não se representa um sujeito que se coaduna aos princípios do colonialismo, simultaneamente, não se conforta como sujeito engajado no contexto político pósindependência. Dessa maneira, acaba por empreender a diáspora e exila-se em outros espaços em que possa se sentir habitado de sentido, encontrando em sua poética, o refúgio para escapar ao não-pertencimento. 


\section{Referências}

AUGÉ, M. Por uma antropologia dos mundos contemporâneos. Rio de Janeiro: Bertrand Brasil, 1997.

- Não Lugares: Introdução a uma antropologia da supermodernidade.

Campinas: Papirus, 2014.

BACHELARD, G. A poética do espaço. São Paulo: Martins Fontes, 1998.

. O ar e os sonhos: ensaio sobre a imaginação do movimento. São

Paulo: Martins Fontes, 2009a.

. A poética do Devaneio. São Paulo: Martins Fontes, 2009b.

BAUMAN, Z. Identidade. Rio de Janeiro: Jorge Zahar Editor, 2005.

. Comunidade: a busca por segurança no mundo atual. Rio de Janeiro:Jorge Zahar Editor, 2003.

BHABHA, H. O Local da Cultura. Belo Horizonte: Editora da UFMG, 2007.

. O Bazar Global e o Clube dos Cavalheiros Ingleses: Textos Seletos. (org.)

COUTINHO, E. Rio de Janeiro: Editora Rocco, 2011.

CABAÇO, José Luís. Moçambique: Identidade, Colonialismo e Libertação. São Paulo: Editora UNESP, 2009.

CÉSAIRE, Aimé. Discurso sobre o Colonialismo. Lisboa: Editora Sá da Costa, 1978.

CHABAL, P. Vozes Moçambicanas: Literatura e Nacionalidade. 1. edição Lisboa: Vega, 1994.

DELEUZE, Gilles; PARNET, Claire. Diálogos. São Paulo: Escuta, 1998.

FANON, F. Pele Negra, Máscaras Brancas. Salvador: EDUFBA, 2008.

HALL, S. Da Diáspora: Identidades e Mediações Culturais. (org.). SOVIK, L. Belo Horizonte: Editora da UFMG, 2003.

HALL, S. Quem precisa de identidade? In: SILVA, T.T. (org.), HALL, S.,

WOODWARD, K. Identidade e diferença: A perspectiva dos estudos culturais. Petrópolis: Vozes, 2000. p.103-133. 
2011.

. A Identidade Cultural na Pós-Modernidade. Rio de Janeiro: DP\&A Editora,

KNOPFLI, R. Obra Poética. Lisboa: Editorial da INCM, 2003.

MACAGNO, Lorenzo. Fragmentos de uma Imaginação Nacional. In Revista Brasileira de Ciências Sociais vol.24 n.70, 2009.

MACHEL, Samora. Educar o homem para vencer a guerra, criar uma sociedade nova e desenvolver a pátria. Coleção Palavras de Ordem. Departamento de Trabalho Ideológico. Maputo, FRELIMO, 1978.

MBEMBE, Achille. Sair da Grande Noite: Ensaio sobre a África Descolonizada. Lisboa: Edições Pedago, 2014.

MONTEIRO, F. O país dos outros: a poesia de Rui Knopfli. Lisboa: Editorial da INCM, 2003.

RANCIÈRE, J. Políticas da Escrita. Rio de Janeiro: Editora 34, 1995.

. O Desentendimento: política e filosofia. São Paulo: Editora 34, 1996.

SAID, E. Representações do Intelectual. Lisboa: Edições Colibri, 2000.

Fora do Lugar. São Paulo: Companhia das Letras, 2004.

. Cultura e Imperialismo. São Paulo: Companhia das Letras, 2011.

SANTOS, Boaventura Sousa. "Entre Próspero e Caliban: colonialismo, póscolonialismo e interidentidade." In: Entre ser e estar - raizes, percursos e discursos da identidade. Porto: Afrontamento, 2002.

SUBIRATS, Eduardo. A existência sitiada. São Paulo: Romano Guerra Editora, 2010.

Recebido 01/07/2019

Aprovado 24/07/2019 